\title{
Identification of copy number alterations associated with the progression of DCIS to invasive ductal carcinoma
}

\author{
C Johnson ${ }^{1,2+}$, KL Gorringe $^{1,2^{*}+}$, ER Thompson ${ }^{1}$, K Opeskin ${ }^{3}$, SE Boyle ${ }^{1}$, Y Wang ${ }^{4}$, P Hill ${ }^{3}$, GB Mann ${ }^{5+}$, IG Campbell ${ }^{1,2+}$ \\ From Familial Aspects of Cancer 2011 Research and Practice: A combined meeting of kConFab, Australian \\ Breast Cancer Family Study, Australian Colorectal Cancer Family Study, Australian Ovarian Cancer Study, \\ Family Cancer Clinics of Australia and New Zealand and kConFab \\ Kingscliff, Australia. 23-26 August 2011
}

Ductal carcinoma in situ (DCIS) is a non-obligate precursor to invasive ductal carcinoma (IDC). Identification of the genetic differences between the two lesions may assist in identifying genes that promote the invasive phenotype. To annotate these alterations we analysed 21 breast tumours containing synchronous areas of DCIS and IDC. Tumour cells were microdissected from FFPE tissue and analysed by $300 \mathrm{~K}$ Molecular Inversion Probe (MIP) copy number arrays. Matched IDC and DCIS showed highly similar copy number profiles (average of $83 \%$ of the genome shared). Four regions of loss (3q, 6q, $8 p$ and 11q) and four regions of gain (5q, 16p, 19q and 20) were recurrently affected in IDC but not in the matching DCIS. CCND1 and MYC showed increased amplitude of gain in IDC. One region of loss (17p11.2) was specific to DCIS. Our data shows that DCIS is an advanced pre-invasive tumour with genetic instability and continues to evolve in parallel with co-existing IDC. In the IDC-specific regions of genomic alteration we have identified novel loci as well as genes with previous links to breast cancer progression.

\footnotetext{
Author details

${ }^{1}$ VBCRC Cancer Genetics Laboratory, Peter MacCallum Cancer Centre, East Melbourne, Victoria, Australia. ${ }^{2}$ Department of Pathology, University of Melbourne, Melbourne, Victoria, Australia. ${ }^{3}$ Department of Anatomical Pathology, St Vincent's Hospital, Fitzroy, Victoria, Australia. ${ }^{4}$ Affymetrix Inc, Santa Clara, USA. ${ }^{5}$ The Royal Melbourne and Royal Women's Hospitals, Parkville, Victoria, Australia.
}

\footnotetext{
† Contributed equally

${ }^{1}$ VBCRC Cancer Genetics Laboratory, Peter MacCallum Cancer Centre, East Melbourne, Victoria, Australia
}

Full list of author information is available at the end of the article
Published: 12 April 2012

doi:10.1186/1897-4287-10-S2-A93

Cite this article as: Johnson et al:: Identification of copy number alterations associated with the progression of DCIS to invasive ductal carcinoma. Hereditary Cancer in Clinical Practice 2012 10(Suppl 2):A93.

Submit your next manuscript to BioMed Central and take full advantage of:

- Convenient online submission

- Thorough peer review

- No space constraints or color figure charges

- Immediate publication on acceptance

- Inclusion in PubMed, CAS, Scopus and Google Scholar

- Research which is freely available for redistribution

Submit your manuscript at www.biomedcentral.com/submit

C BioMed Central 